\title{
Is the transition from biparental to male-only care in a monogamous seabird related to changes in body mass and stress level?
}

\author{
Katarzyna Wojczulanis-Jakubas • Dariusz Jakubas • \\ Dorota Kidawa • Anna Kośmicka
}

Received: 24 February 2011/Revised: 27 October 2011/ Accepted: 6 December 2011/Published online: 29 December 2011

(C) The Author(s) 2011. This article is published with open access at Springerlink.com

\begin{abstract}
In a number of species with biparental care, the parents of one sex desert the mate and brood before the chick is independent. The reasons for this desertion are poorly understood. In the study reported here we investigated whether sex-specific changes in body mass corrected for size (in short body mass) and the stress-related heterophil to lymphocyte ratio (H:L) during the late incubation and chick-rearing period are related to female brood desertion in a small Arctic seabird, the Little Auk (Alle alle). The body mass of both sexes did not change during the study periods, although females were significantly lighter than males. No sex differences were found in the pattern of changes in the H:L ratio. In both sexes, the H:L ratio, and thus the stress level, increased significantly just after hatching and remained high until the last week of chick rearing when it fell back to the level recorded during incubation. These results support behavioural reports of an equal male and female contribution to parental care. The similar body condition of males and females undermines the hypothesis on the depletion of female body reserves as the main trigger of their earlier brood desertion. It is possible that a sex-specific role in parental care during and after fledging and/or an ancestral pattern of parental care are responsible for the transition to paternal care in Little Auks.
\end{abstract}

Communicated by P. H. Becker.

\footnotetext{
K. Wojczulanis-Jakubas ( $($ ) · D. Jakubas · D. Kidawa ·

A. Kośmicka

Department of Vertebrate Ecology and Zoology,

University of Gdańsk, al. Legionów 9,

Gdańsk 80-441, Poland

e-mail: biokwj@univ.gda.pl
}

Keywords Biparental care - Body mass - Heterophil to lymphocyte ratio $\cdot$ Little Auk $\cdot$ Stress level

\section{Zusammenfassung}

Gibt es einen Zusammenhang zwischen dem Übergang von zwei-geschlechtlicher Brutfürsorge zu rein männlicher Brutfürsorge und Veränderungen in Körpergewicht und Stresslevel in einer monogamen Seevogelart?

In einer ganzen Reihe von Vogelarten mit zwei-geschlechtlicher Brutfürsorge verlässt das Elternteil eines Geschlechtes seinen Partner und die Brut bereits vor dem Flüggewerden der Küken. Über die Gründe dieses Verhaltens ist jedoch nicht viel bekannt. Hier haben wir in einer kleinen, arktischen Seevogelart, dem Krabbentaucher (Alle alle), untersucht, ob geschlechtsspezifische Veränderungen im Größenkorrigiertem Gewicht (kurz: Gewicht) und dem mit Stress assoziiertem Verhältnis heterophiler Blutkörperchen zu Lymphozyten (H:L Ratio) während der Brut- und Kükenaufzuchtsperiode mit dem Verlassen der Brut durch Weibchen assoziiert sind. In beiden Geschlechtern veränderte sich das Gewicht nicht während des Untersuchungszeitraumes, und Weibchen waren signifikant leichter als Männchen. Wir fanden keine Geschlechterunterschiede im H:L Ratio. Kurz nach der Schlupf nahm das H:L Ratio in beiden Geschlechtern signifikant zu, um dann in der letzten Woche der Kükenaufzuchtsperiode wieder auf ein ähnliches Niveau wie während der Brutperiode gemessen abzufallen. Diese Ergebnisse unterstützen die Verhaltensbeobachtung von gleichem Elterninvestment zwischen den Geschlechtern. Die ähnliche Körperkondition von Männchen und Weibchen unterstützt die Hypothese, dass eine Erschöpfung von weiblichen Energiereserven ein möglicher Auslöser ist. Es ist möglich, dass eine geschlechtsspezifische Rolle in der 
elterlichen Fürsorge während oder nach dem Flüggewerden der Jungen und/oder ein Muster elterlicher Fürsorge der Ahnen verantwortlich für den Übergang der elterlichen Fürsorge bei Krabbentauchen ist.

\section{Introduction}

Parental investments are governed by a trade-off between the benefits and costs of resources allocated to current versus potential future reproductive performance (CluttonBrock and Vincent 1991; Stearns 1992). To reconcile their own survival and that of their offspring, animals use a variety of strategies involving both behavioural and physiological changes during reproduction. The majority of avian species perform biparental care (Cockburn 2006). For many ecological groups, and seabirds above all, this is an obligatory breeding system, and the lapse of one parent's contribution leads to breeding failure (Gowaty 1996). Biparental care also increases the parents' survival by conserving their energy resources. Nevertheless, because of anatomical, physiological, behavioural and ecological constraints, the level of the contribution to particular activities, or specific parental roles, even in biparental systems may vary between sexes (Trivers 1972; Bart and Tornes 1989; Elliot et al. 2010). Sex-specific contributions/ roles in parental care may lead to sex-specific modulations of body condition, and this in turn may affect male and female decisions on further energy allocation into offspring.

In a number of species characterized by biparental care, the parents of one sex desert the mate and brood before the chick is independent (Oring 1982; Davies 1991). The reasons for this desertion are usually poorly understood. There are basically two hypotheses, both founded on life-history theory, with a sexual conflict being involved. One concerns the re-mating opportunity of the deserting sex. Particularly when resources are ample, one parent may try to escape parental duties and increase its reproductive output with another breeding attempt (Davies 1991; Andersson 2005; Eldegard and Sonereud 2009). However, this explanation is plausible only in groups/ species in which the desertion occurs at a relatively early stage of breeding and there is time for a second breeding attempt. The second hypothesis takes the differential capacity and/or roles of the parents into consideration and usually assumes that the female is the sex more vulnerable to experiencing body reserve depletion. According to this hypothesis, a female deserting the brood is approaching a critical level of her own body reserves, which are diminishing as a result of earlier incurred parental costs, including egg production (Erckmann 1983). Alternatively, it has been hypothesized that the parent staying with the offspring may somehow be predisposed to perform particular activities more than the deserting parent (e.g. Paredes and Insley 2010).
In this study we investigated whether the transition from biparental to male-only care is related to sex-specific changes in some body condition parameters during the late incubation and chick-rearing period in a small (130-200 g), colonially breeding, high-Arctic seabird, the Little Auk (Alle alle). The Little Auk is socially and genetically monogamous (Lifjeld et al. 2005; WojczulanisJakubas et al. 2009a) with a very slight sexual dimorphism (males have larger total head length than females; Jakubas and Wojczulanis 2007). A female produces one egg annually. Little Auks, together with the Brünnich's Guillemot (Uria lomvia), the Common Guillemot (Uria aalge) and Razorbill (Alca torda), constitute the tribe Alcini, the members of which are noted for displaying the transition from biparental to paternal care. Chicks of all four species are escorted by the male parent during their first journey to sea, where exclusively paternal care (guiding and leading to good foraging areas) is believed to be continued for the next few weeks (Sealy 1973; Harris and Birkhead 1985; Stempniewicz 1995; Gaston and Jones 1998; Harding et al. 2004; Paredes et al. 2006). However, Little Auk chicks depart the colony later and are better developed (approx. 27 days after hatching with $68-72 \%$ of adult body mass; Stempniewicz 1995; Harding et al. 2004) than those of other species of the tribe (15-20 days after hatching with 15-30\% of adult body mass; Sealy 1973; Gaston and Jones 1998). Female desertion of parental care in both the Little Auk and the three other Alcini species is far from being understood. The relatively long nesting period of biparental care and the short time window for breeding in the high Arctic renders the re-mating hypothesis inapplicable to Little Auks, and only the hypothesis of differential capacity and/or roles of the parents can be considered a viable explanation.

Studies of Little Auks that have compared male and female parental care at various stages of breeding indicate similar, if not male-biased parental efforts (Stempniewicz and Jezierski 1987; Harding et al. 2004; WojczulanisJakubas et al. 2009b). However, Taylor (1994) showed that Little Auk females had a body mass similar to that of males during the incubation period but not during chick rearing, when they are significantly lighter than males. This finding may indicate a differential male and female response to the same parental burden.

To examine the role of the birds' body condition in female brood desertion, we used body mass corrected for body size (hereafter named body mass) and the heterophil to lymphocyte $(\mathrm{H}: \mathrm{L})$ ratio, which is an indicator of stress level. Body mass is easily determined and has been widely used as a measure in similar studies (e.g. Taylor 1994; Amat et al. 2000; Williams et al. 2007). A marked decline in a bird's body mass is usually associated with an increase in parental effort (Croll et al. 1991; Jones 1994; Phillips 
and Furness 1997). The H:L ratio is often used as an index of the level of response to various stressors, such as infectious diseases or starvation, but it is also an index of parental performance (reviewed in Davis et al. 2008; Gladbach et al. 2010; Dehnhard et al. 2011). For example, in Upland Geese Chloephaga picta leucoptera, higher H:L ratios were recorded in individuals with a lower body mass and caught later in the breeding season (Gladbach et al. 2010). This stress-related measure has the advantage of being less variable and longer lasting than the corticosterone stress response and is not influenced by a handling time of up to $1 \mathrm{~h}$ (Davis 2005; Davis et al. 2008).

If brood desertion by Little Auk females is indeed induced by body reserve depletion, in line with the differential capacity hypothesis, we should expect females to have a lower body mass and a higher stress level than males, with differences between sexes being particularly well pronounced at the end of the breeding period.

\section{Materials and methods}

Study area and field work

The fieldwork was conducted in the Little Auk breeding colony on a moraine slope of the Buchanbreen glacier in Magdalenefjorden in NW Spitsbergen $\left(79^{\circ} 33^{\prime} \mathrm{N}, 10^{\circ} 52^{\prime} \mathrm{E}\right)$ in July-August 2008 and 2009.

Data on body mass and the H:L ratio were collected systematically during the five phases of the breeding season, which can be distinguished by variations in parental activities during the nesting period (Harding et al. 2004; Wojczulanis-Jakubas et al. 2009b) and the pattern of chick development. In our study, the latter was determined on the basis of published data (Stempniewicz 1980; Gaston 1985, Konarzewski and Taylor 1989) and our own raw body mass measurements of chicks from 36 nests in 2008. The chicks were weighed with an electronic balance (accurate to $0.1 \mathrm{~g}$; OHAUS, Nänikon, Switzerland) every 3 days starting from days 1-3 of life until fledging. Cut-off points of the different breeding phases were distinguished for each season according to the respective median date of hatching. To establish the median date of hatching, we monitored a group of 36 nests in 2008 and a group of 53 nests in 2009 every 2 days, beginning from late incubation and continuing to the hatching of the last chick in the group of nests. The hatching was quite synchronous in the colony studied, with most chicks $(>83 \%)$ hatching within 1 week in both seasons. The first phase distinguished was the second half of the incubation (2-14 days before hatching), during which time the principal activity of the parent birds was to warm the egg (Wojczulanis-Jakubas et al. 2009b). The four other phases were the consecutive weeks of the chickrearing period. During the first week of chick rearing (chicks 1-7 days old), both Little Auk parents brood and provision the chick at a rate of two to five feedings per day (Stempniewicz and Jezierski 1987; Harding et al. 2004; Wojczulanis-Jakubas 2007). In the second week of chick rearing (chicks 8-14 days old), the adults gradually reduce brooding but continue to feed at a similar frequency (Harding et al. 2004; Wojczulanis-Jakubas 2007). The first 2 weeks of chick rearing are when the chicks show the most intensive chick rate (approx. $20 \mathrm{~g}$ per 3 days; Stempniewicz 1980; Gaston 1985; Konarzewski and Taylor 1989; this study). The feeding rate in the third week of chick rearing (chicks 15-21 days old) is similar to that of earlier weeks (Stempniewicz and Jezierski 1987; Harding et al. 2004; Wojczulanis-Jakubas 2007), but the growth rate of chicks is slower (approx. $9 \mathrm{~g}$ of body mass per 3 days; Stempniewicz 1980; Gaston 1985; Konarzewski and Taylor 1989; this study), primarily due the growing chicks' wing exercising activities outside the nest chamber (Stempniewicz 1995). During the fourth and last week of chick rearing (chicks $>21$ days old), females cease feeding their offspring and leave the colony, thereby providing one of the probable explanations of the observed very slow chick growth and body mass recession during that period (Stempniewicz 1980; Harding et al. 2004; WojczulanisJakubas 2007). The exact time of when females cease to feed their chick remains to be studied, but our observations to date (unpublished data) indicate that most females disappear from the colony 3 days before their chick fledge, while some may stay until the end of nesting period.

Birds were captured either with mist nets and noose carpets spread over the colony area (the same as for hatching controls) or taken directly from nests while incubating, brooding or feeding. Although the exact hatching time was not known for all of the birds captured in our study, the synchrony of hatching in the monitored group of nests allowed us to assume a similar phase of breeding for the individuals sampled at the same time. Only adults ( $\geq 2$ years of age), which can be distinguished from subadults based on the appearance of flight feathers and upper wing coverts in the former (Stempniewicz 2001), with a large brood patch (incubation) or gular pouch full of food (chick rearing), an indication of breeding, were considered in the study. The captured birds were ringed, measured (wing and head-bill length) and weighed (with a $300 \mathrm{~g}$ spring balance, accurate to $1.0 \mathrm{~g}$; Pesola, Blickensdorf, Switzerland), after which approximately $20 \mu \mathrm{l}$ of blood was taken from the brachial vein. Each bird was sampled only once. Part of each collected blood sample was used for leukocyte analysis; the remainder of each sample taken was stored in $1 \mathrm{ml} 96 \%$ ethanol until used for DNA-based sex identification. Birds were released after 
Table 1 Sample sizes for body mass and leucocyte parameters for both sexes of the Little Auk (Alle alle) in each breeding phase in the two study seasons

\begin{tabular}{lrrrrr}
\hline Breeding phase $^{\mathrm{a}}$ & \multicolumn{2}{c}{ Females $(n)$} & & \multicolumn{2}{c}{ Males $(n)$} \\
\cline { 2 - 3 } \cline { 6 - 7 } \cline { 5 - 6 } & 2008 & 2009 & & 2008 & 2009 \\
\hline Late incubation & 11 & 30 & & 22 & 33 \\
Chick rearing, week 1 & 6 & 10 & & 9 \\
Chick rearing, week 2 & 27 & 13 & & 31 & 11 \\
Chick rearing, week 3 & 12 & 13 & & 9 & 11 \\
Chick rearing, week 4 & 8 & 1 & & 28 & 2 \\
\hline
\end{tabular}

${ }^{a}$ According to the median date of hatching for each season

10-15 min of handling without any harm. A total of 164 males and 131 females were captured (Table 1).

Since the parental effort (number of feeding and foraging time) of Little Auks may vary in different breeding colonies and seasons (e.g. Jakubas et al. 2007, 2011), in both seasons we continuously observed ( $24 \mathrm{~h} /$ day) individually marked parents from nests with a known hatching date. Timing of the observation was aimed at the mid chick-rearing period, when chicks are already homeothermic (Konarzewski and Taylor 1989) but they still show intensive growth (Stempniewicz 1980; Gaston 1985; Konarzewski and Taylor 1989; this study). The observations were performed when the chicks were on average 12 and 16 days old in 2008 and 2009, respectively. In order to be able to follow the birds during these observations, we marked both breeding mates from 36 different nests (16 in 2008 and 20 in 2009) that had been captured at the end of the incubation period with unique dyed characters on the breast feathers and a combination of coloured rings. A blood sample for molecular sexing was taken from each marked bird. All nests were situated in close proximity of each other within a small $\left(200 \mathrm{~m}^{2}\right)$ colony patch, allowing two observers to follow all marked birds. A bird that appeared after an absence in the colony patch with full gular pouch and which entered the nest was regarded as feeding. The number of feedings was calculated per $24 \mathrm{~h}$ per bird. Total time spent outside the colony (total time spent on foraging trips) was calculated based on the presence/absence of marked individuals from the studied colony patch-with continuously monitoring and readings made at least every $10 \mathrm{~min}$.

\section{Laboratory work}

The blood smears were air dried, then stained using the May-Grünewald-Giemsa method and examined under a compound microscope at a magnification of $1,000 \times$ with oil immersion. Leukocytes, with respect to their type, were counted until the cumulative total was 100 cells. All types of leukocytes were counted, but only data on heterophils and lymphocytes were used in the study owing to the small number of other leukocytes (basophils, eosinophils and monocytes). DNA for sexing was extracted from coagulated blood (after ethanol evaporation) using a Blood Mini kit (A\&A Biotechnology, Gdynia, Poland). CHD genebased analyses were performed with the primer pair F2550 and R2718, according to Griffiths et al. (1998) using a $50^{\circ} \mathrm{C}$ annealing temperature for the PCR reaction. The sex differences in the PCR products were clearly visible when the fragments were separated on a $2 \%$ agarose gel and stained with ethidium bromide.

\section{Data analysis}

Owing to the lack of data for the last week of the chickrearing period in 2009 (only two males and one female sampled; Table 1), two separate approaches were applied. In the first, data from the corresponding phases of breeding from the two seasons (i.e. incubation and the first 3 weeks of chick rearing) were used, and in the second, data from all phases of breeding but only from one season (2008) were included.

General linear models (GLMs) were used to test for sex, breeding phase and season differences in body mass and $\mathrm{H}: \mathrm{L}$ ratio. Body mass was analysed using analysis of covariance (ANCOVA) (García-Berthou 2001) with sex, breeding phase and season as independent variables and head-bill length as a covariate. When data from one season only were analysed, the season variable was excluded from the model. Head-bill length was chosen as a body size covariate since this is the one morphological character that differentiates the sexes (Jakubas and Wojczulanis 2007). $\mathrm{H}: \mathrm{L}$ ratios were analysed using factorial ANOVA with sex, breeding phase and season as independent variables. In these analyses also, when data from one season only were analysed, the season variable was excluded from the model. The Newman-Keuls test was used as a post hoc test in all GLM analyses. Multiple regression was used (Freckleton 2002) to evaluate the influence of the birds' body size (i.e. head-bill length) and H:L ratio on their body mass, separately for males and females

Differences between the sexes and two seasons in feeding rate and foraging time were tested using factorial ANOVA, with season and sex as independent variables. The Newman-Keuls test was used for a post hoc testing.

All data were tested for homogeneity of variance (Leven's test) and normality (Kolmogorov-Smirnov test). To approach the normality of the H:L data, arcsin squareroot transformation was applied (Zar 1999). After such treatment all data satisfied the assumptions of the GLMs. The statistical analyses were performed using Statistica 8.0 (StatSoft, Tulsa, OK). 


\section{Results}

In the first model (two seasons, breeding period without the last phase of chick rearing), body mass of Little Auks was found to be significantly influenced by body size (ANCOVA $\left.F_{1,239}=12.27, P=0.001\right), \operatorname{sex}\left(F_{1,239}=5.74, P=0.02\right)$ and season $\left(F_{1,239}=5.39, P=0.02\right)$, but not by breeding phase $\left(F_{3,239}=2.17, P=0.92\right)$. Interaction between body mass and both categorical predictors was not significant $\left(F_{3,244}=0.60, P=0.62\right)$. The birds had a lower body mass in 2008 than in 2009 (Newman-Keuls test $P<0.05$ ), and males were generally heavier than females (Newman-Keuls test $P<0.05$ ). In the second model (one season with all phases of breeding), body mass of Little Auks was found to be significantly influenced only by body size (ANCOVA $\left.F_{1,151}=14.04, P<0.001\right)$, but not by $\operatorname{sex}\left(F_{1,151}=2.63\right.$, $P=0.11)$ or phase of breeding $\left(F_{4,151}=0.28, P=0.89\right.$; Fig. 1). Also, interaction between body mass and both the categorical predictors was not significant $\left(F_{4,151}=0.58\right.$, $P=0.68)$.

Factorial ANOVA performed on the two-season dataset revealed that $\mathrm{H}: \mathrm{L}$ in breeding birds was significantly influenced by breeding phase $\left(F_{3,240}=3.51, P=0.02\right)$ and season $\left(F_{1,240}=20.91 ; \quad P<0.001\right)$ but not by sex $\left(F_{1,240}=0.10 ; P=0.75\right)$. The sex $\times$ phase of breeding $\times$ season interaction was not significant $\left(F_{3,240}=0.77\right.$, $P=0.51)$. The birds had a higher H:L ratio in 2008 than in 2009. Birds of both sexes had a significantly lower H:L at the end of the incubation period than in the second and third week of the chick-rearing period (Newman-Keuls test $P<0.05$ ). In the approach using the data set from 2008 only, the H:L ratio in breeding birds was significantly influenced by breeding phase $\left(F_{4,152}=6.55, P<0.001\right)$ but not by sex $\left(F_{1,152}=0.54 ; P=0.47\right) ;$ no sex $\times$ phase of breeding

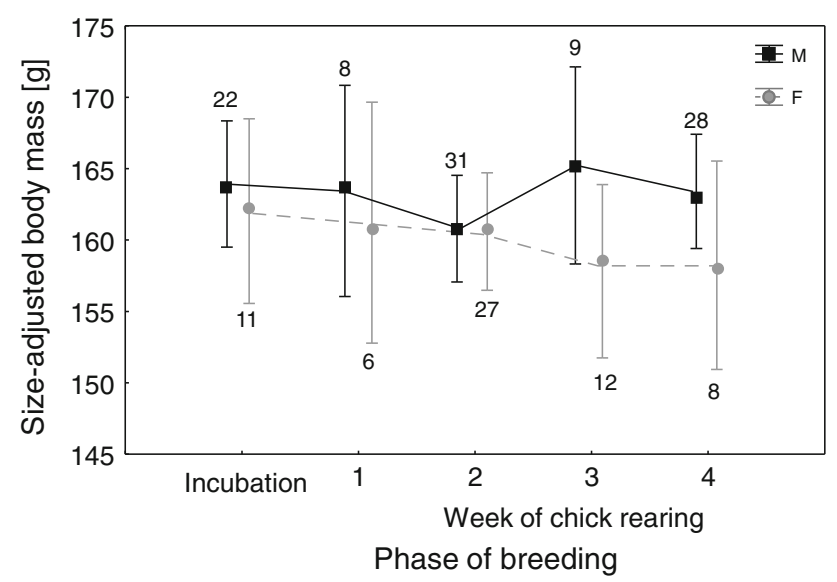

Fig. 1 Body mass corrected for size of Little Auk (Alle alle) males $(M)$ and females $(F)$ [mean \pm 0.95 confidence intervals $(\mathrm{CI})]$ at the end of incubation and during the whole chick-rearing period in season 2008. The numbers above and below the bars denote sample size.

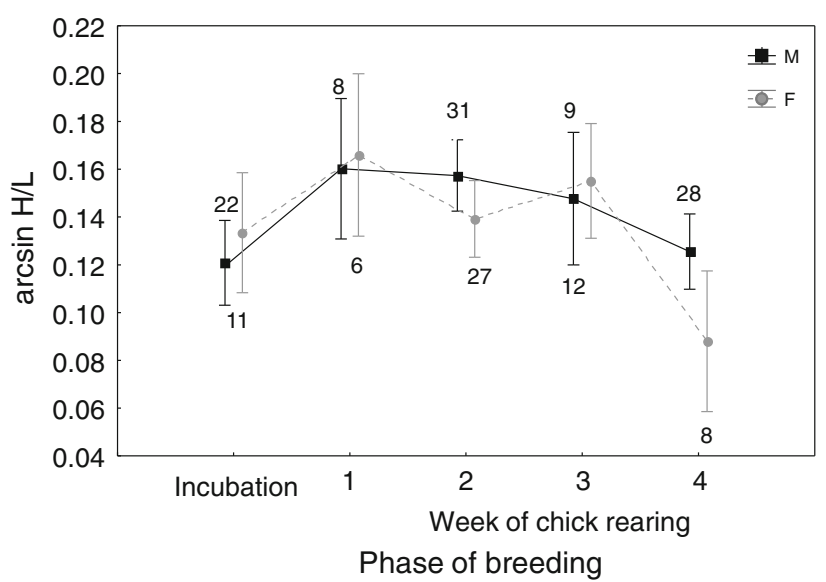

Fig. 2 Stress-related heterophil to lymphocyte ratio (H:L: $\arcsin$ root transformed) in Little Auk males and females (mean $\pm 0.95 \mathrm{CI}$ ) at the end of incubation and during the whole chick-rearing period in season 2008. The numbers above and below the bars denote sample size

interaction was revealed $\left(F_{4,152}=1.73, P=0.15\right)$. The $\mathrm{H}: \mathrm{L}$ values of birds of both sexes were similar at the end of the chick-rearing period to those recorded at the end of incubation, and both were significantly lower than those noted during the first 3 weeks of the chick-rearing period (Newman-Keuls test $P<0.05$; Fig. 2).

Multiple regression performed for males showed that body mass was significantly influenced $\left(R^{2}=0.11\right.$, $\left.F_{2,161}=9.61, P<0.001\right)$ by body size (i.e. head-bill length; $\beta=0.33$ ) but not by the $\mathrm{H}: \mathrm{L}$ ratio $(\beta=0.02)$. In contrast, in females $\left(R^{2}=0.01, F_{2,128}=1.80, P=0.17\right)$, neither body size $(\beta=0.17)$ nor $\mathrm{H}: \mathrm{L}$ ratio $(\beta=-0.02)$ influenced body mass.

The birds performed similar a number of feedings regardless of season [mean \pm standard deviation (SD) in 2008: $4.2 \pm 1.71$ and $4.2 \pm 1.74$ in 2009; factorial ANOVA $\left.F_{1,68}=0.27, P=0.61\right]$ and sex (males $4.5 \pm$ 1.44 , females $\left.4.1 \pm 1.95 ; F_{1,68}=1.07, P=0.30\right)$. The interaction between sex and season was not significant $\left(F_{1,68}=0.63, P=0.43\right)$. Significant interannual differences were found in terms of total foraging time (factorial ANOVA $F_{1,68}=4.26, \quad P=0.43$; Newman-Keuls test $P<0.05$ ), with a higher value for season 2008 (mean \pm SD: $19.8 \pm 3.14 \mathrm{~h})$ compared to $2009(18.3 \pm 2.94 \mathrm{~h})$. However, sex did not influence total foraging time (males $18.80 \pm 3.09 \mathrm{~h}$, females $19.16 \pm 3.15 \mathrm{~h} ; F_{1,68}=0.25$, $P=0.62)$. The sex and season interaction was also insignificant $\left(F_{1,68}=0.01, P=0.92\right)$.

\section{Discussion}

No sex differences were found in either the Little Auk's body mass or in the pattern of changes in the stress level of 
birds (expressed by the H:L ratio) during the whole study period. These results indicate similar male and female contributions to parental care and are basically consistent with reported behavioural data (Stempniewicz and Jezierski 1987; Harding et al. 2004; Wojczulanis-Jakubas et al. 2009b; this study). The lack of sex differences in the tested parameters at the beginning of the chick-rearing period suggests that the females have recovered from their initial energy investment in egg production. This restoration of reserves is likely to have been achieved by increasing food intake prior to egg-laying (Williams 2005; own unpublished data) and/or during incubation (Jakubas et al. 2008). Also during the chick-rearing period, the current energy demands of both sexes seemed to be covered without their body reserves becoming depleted. Consequently, at the end of breeding season Little Auk males and females were in a similar physiological state.

Our results undermine the hypothesis regarding the depletion of female body reserves as a cause of their earlier brood desertion. In such a contex, a sex-specific role in parental care during and after fledging might be an alternative explanation of the transition from biparental to paternal care in Little Auks. Owing to predatory pressure on the part of the Glaucous Gull (Larus hyperboreus), colony departure is a highly vulnerable moment in the life of a Little Auk chick (Stempniewicz 1995; Wojczulanis et al. 2005). To increase the chances of chick survival in the case of a gull attack, the escorting adult male performs a manoeuvre that is supposed to distract the predator (Stempniewicz 1995). Being somewhat larger and presumably also more aggressive, the male parent may be more capable of protecting the chick than the female. Razorbill males were found to be more specialized than females in the defence of their brood. When a model of the main predator was presented, males displayed aggressive behaviour more frequently than females, whereas females either showed no response or responded with self-protective behaviour more often than males (Paredes and Insley 2010). Another point is parent-offspring recognition, which seems to be mandatory for chick survival during and after colony departure. While fledging, the chick is in constant vocal contact with the escorting parent (Stempniewicz 1995; own observations). In Razorbills, it is only the male that appears to recognize its chick's call, or at least respond to it (Insley et al. 2003). However, sex-biased efficiency in chick defence and/or parent-offspring vocal recognition in the Little Auk requires further study.

Considering the universality of the transition from biparental to paternal care in the Alcini tribe, it is also likely that female brood desertion in Little Auks is simply associated with an ancestral pattern of parental care. Overall, in charadriiform birds, male-biased care of the chick is more common than female-biased care. The origin of this pattern is controversial. One hypothesis postulates that biparental care was ancestral and that the uniparental system evolved subsequently, depending on the differences in the costs of care and the benefits of desertion (Jenni 1974; Emlen and Oring 1977). Alternatively, the male- to biparental care hypothesis suggests that the earliest forms of male care were followed by female care as males reduced their contributions. In any case, once the hormonal or neural pathways were established in Alcini ancestors, it could be "easy" to revert to the paternal state when biparental care did not increase fitness for a particular breeding phase.

Little Auks, having relatively high wing load, are expected to exhibit adaptive mass loss during the breeding, similar to other members of the Alcidae family (e.g. Brünnich's Guillemot; Croll et al. 1991). Such a loss of body mass at the beginning of the chick-rearing period might be a means of increasing flight efficiency for the most demanding time of breeding in terms of flight performance. Indeed, Taylor (1994), who examined body mass in Little Auks in a breeding colony in Hornsund, found an abrupt fall in body mass soon after hatching. However, this was not found to be the case in our study. The reason for this apparent discrepancy between Taylor's (1994) and our study may be differences in the breeding conditions of the two areas. The present study site, Magdalenefjorden, is a trophically much less favourable area than Hornsund. Birds from Magdalenefjorden are forced to forage in suboptimal food conditions nearby the colony and/or to perform longer foraging trips $(>100 \mathrm{~km}$, to the edge of sea ice; Jakubas et al. 2012) than birds from the colony in Hornsund (Kwasniewski et al. 2010). The inferior conditions in Magdalenefjorden may cause only a small increase in Little Auk body mass during the incubation period, as was found to be the case in the Wilson's Storm Petrel Oceanites oceanicus. The mass of the adult petrels during incubation was high in good seasons but low in poor ones (Quillfeldt et al. 2006). Consequently, Little Auks from Magdalenefjorden may exhibit a less pronounced decline in body mass after hatching, since for birds having an already lower body mass the adaptive mass loss might be less beneficial. Jacobs et al. (2011) put forward a similar argument for Kittiwakes (Rissa tridactyla): in a poor year the birds did not show the typical, adaptive loss of body mass.

The lower body mass and elevated stress level of the Little Auks in 2008 suggest an adverse breeding conditions compared to 2009. Indeed, comparison of parental efforts between those two seasons revealed that the birds spent more time on foraging in 2008. The results support recent experimental evidence that a decrease in body mass is associated with increased foraging costs in the Little Auks (Harding et al. 2009a, b). It is interesting that even birds operating in such suboptimal conditions as in 
Magdalenefjorden were still able to adaptively regulate their body mass and stress level.

Contrary to body mass, the pattern of changes in the H:L ratio in Little Auk adults seems to reflect quite well their parental effort in the consecutive phases of breeding. The $\mathrm{H}: \mathrm{L}$ ratio increased in both sexes after hatching, thus along with the increase in parental effort associated with brooding and feeding the chick. Surprisingly, however, in the fourth week of the chick-rearing period, when the male and female (if still present) were feeding the chick with the same frequency as in previous weeks (Wojczulanis-Jakubas 2007), the H:L ratio fell to the incubation level in both sexes. This could indicate the initiation of an internal mechanism preparing adults to bring breeding activities to an end and/or to initiate moulting, as lowered H:L ratios are reported in moulting birds (e.g. Driver 1981; Hawkey et al. 1989; Sanz et al. 2004).

Summing up, in the light of our results, the body mass and stress level of the Little Auk do not seem to be prime reasons for the cessation of parental care. However, further research into the physiological state of breeding birds is needed. A study measuring the level of prolactin, which is believed to control parental behaviour (e.g. Buntin 1996), could provide insight into the mechanisms governing the earlier ending of breeding in Little Auk females. Also, testing the sex-specific role in parental care during and after fledging may help to understand the transition to uniparental care. Finally, as the depletion of female body reserves after laying may depend on their breeding experience (e.g. Bauch et al. 2011), a study considering this factor in Little Auks would be valuable.

Acknowledgments Our thanks go to Lech Iliszko, Gosia Jakimiak and Wojtek Iliszko for their assistance in the field and to Kyle Elliot for her valuable comments on a previous version of the manuscript. We appreciate the improvements in English usage made by Peter Senn and through the Association of Field Ornithologists' program of editorial assistance. All field work was done with the permission of the Norwegian Animal Research Committee and the Governor of Svalbard. The study was supported by a grant from Norway through the Norwegian Financial Mechanism (ALKEKONGE, PNRF-234-AI1/07) and by a grant from Polish Ministry of Science and Higher Education to KWJ (Juventus Plus 0470/P01/2010/70).

Open Access This article is distributed under the terms of the Creative Commons Attribution Noncommercial License which permits any noncommercial use, distribution, and reproduction in any medium, provided the original author(s) and source are credited.

\section{References}

Amat JA, Visser GH, Pérez-Hurtado A, Arroyo GM (2000) Brood desertion by female shorebirds: a test of the differential parental capacity hypothesis on Kentish plovers. Proc R Soc Lond B 267:2171-2176
Andersson M (2005) Evolution of classical polyandry: three steps to female emancipation. Ethology 111:1-23

Bart J, Tornes A (1989) Importance of monogamous male birds in determining reproductive success. Evidence for house wrens and a review of male-removal studies. Behav Ecol Sociobiol 24: 109-116

Bauch C, Kreutzer S, Becker PH (2011) Breeding experience affects condition: blood metabolite levels over the course of incubation in a seabird. J Comp Physiol B 180:835-845

Buntin JD (1996) Neural and hormonal control of parental behavior in birds. In: Rosenblatt JS, Snowdon CT (eds) Advances in the study of behavior. Academic Press, San Diego, pp 161-213

Clutton-Brock TH, Vincent AC (1991) Sexual selection and the potential reproductive rates of males and females. Nature 351 : $58-60$

Cockburn A (2006) Prevalence of different modes of parental care in birds. Proc R Soc B 273:1375-1383

Croll DA, Gaston AJ, Noble DG (1991) Adaptive mass loss in thickbilled Murres. Condor 93:496-502

Davies NB (1991) Mating systems. In: Krebs JR, Davis NB (eds) Behavioural ecology: an evolutionary approach. Blackwell Scientific Publications, Oxford, pp 263-294

Davis AK (2005) Effects of handling time and repeated sampling on avian white blood counts. J Field Ornithol 76:334-338

Davis AK, Maney DL, Maerz JC (2008) The use of leukocyte profiles to measure stress in vertebrates: a review for ecologists. Funct Ecol 22:760-772

Dehnhard N, Poisbleaum M, Demongin L, Quillfeldt P (2011) Do leucocyte profiles reflect temporal and sexual variation in body condition over the breeding cycle in Southern Rockhopper Penguins? J Ornithol 152:759-768

Driver EA (1981) Hematological and blood chemical values of mallard, Anas platyrhynchos platyrhynchos, drakes before, during and after remige moult. J Wildlife Dis 17:413-421

Eldegard K, Sonereud GA (2009) Female offspring desertion and male-only care increase with natural and experimental increase in food abundance. Proc R Soc Lond B 276:1713-1721

Elliot KE, Gaston AJ, Crump D (2010) Sex-specific behaviour by monomorphic seabird represents risk partitioning. Behav Ecol 21:1024-1032

Emlen ST, Oring LW (1977) Ecology, sexual selection and the evolution of mating systems. Science 197:215-223

Erckmann WJ (1983) The evolution of polyandry in shorebirds: an evaluation of hypothesis. In: Waser SK (ed) Social behaviour of female vertebrates. Academic Press, New York, pp 113-168

Freckleton RP (2002) On the misuse of residuals in ecology: regression of residuals vs. multiple regression. J Anim Ecol 71: 542-545

García-Berthou E (2001) On the misuse of residuals in ecology: testing regression residuals vs. the analysis of covariance. J Anim Ecol 70:708-711

Gaston AJ (1985) Development of the young in the Atlantic Alcidae. In: Nettleship DN, Birkhead TR (eds) The Atlantic Alcidae. The evolution distribution and biology of the Auks inhabiting the Atlantic Ocean and adjacent water areas. Academic Press, Orlando, pp 319-354

Gaston AJ, Jones IA (1998) Bird families of the world. The Auks Alcidae. Oxford University Press, Oxford

Gladbach A, Gladbach DJ, Quillfeldt P (2010) Variations in leucocyte profiles and plasma biochemistry are related to different aspects of parental investment in male and female upland geese Chloephaga picta leucoptera. Comp Biochem Physiol Part A 156:269-277

Gowaty P (1996) Field studies of parental care in birds: new data focus on question on variation among females. Adv Stud Behav 25:477-531 
Griffiths R, Double MC, Orr K, Dawson RJG (1998) A DNA test to sex most birds. Mol Ecol 7:1071-1075

Harding AMA, Van Pelt TI, Lifjeld JT, Mehlum F (2004) Sex differences in Little Auk Alle alle parental care: transition from biparental to paternal-only care. Ibis 146:642-651

Harding AMA, Kitaysky AS, Hall ME, Welcker J, Karnovsky NJ, Talbot SL, Hamer KC, Gremillet D (2009a) Flexibility in the parental effort of an Arctic-breeding seabird. Funct Ecol 23: 348-358

Harding AMA, Kitaysky AS, Hammer ME, Hall ME, Welcker J, Talbot SL, Karnovsky NJ, Gabrielsen GW, Gremillet D (2009b) Impacts of experimentally increased foraging effort on the family: offspring sex matters. Anim Behav 78:321-328

Harris MP, Birkhead TR (1985) Breeding ecology of Atlantic Alcidae. In: Nettleship DM, Birkhead TR (eds) The Atlantic Alcidae: the evolution, distribution and biology of the Auks inhabiting the Atlantic Ocean and adjacent water areas. Academic Press, London, pp 113-168

Hawkey CM, Horsley DT, Keymer IF (1989) Haematology of wild penguins (Spenisciformes) in the Falkland Islands. Avian Pathol 18:495-502

Insley SJ, Paredes R, Jones I (2003) Sex differences in Razorbill (Alca torda) parent-offspring recognition. J Exp Biol 2026:25-31

Jacobs SR, Edwards DB, Ringrose J, Elliott KH, Weber JM, Gaston AJ (2011) Changes in body composition during breeding: reproductive strategies of three species of seabirds under poor environmental conditions. Comp Biochem Physiol B 158:77-82

Jakubas D, Wojczulanis K (2007) Predicting the sex of Dovekies by discriminant analysis. Waterbirds 30:92-96

Jakubas D, Wojczulanis-Jakubas K, Walkusz W (2007) Response of Dovekies to changes in food availability. Waterbirds 30:421-428

Jakubas D, Wojczulanis-Jakubas K, Kreft R (2008) Sex differences in body condition and hematological parameters in Little Auk Alle alle during the incubation period. Ornis Fen 85:90-97

Jakubas D, Głuchowska M, Wojczulanis-Jakubas K, Karnovsky NJ, Keslinka L, Kidawa D, Walkusz W, Boehnke R, Cisek M, Kwaśniewski S, Stempniewicz L (2011) Different foraging effort does not influence body condition and stress level in little auks. Mar Ecol Prog Ser 432:277-290

Jakubas D, Iliszko L, Wojczulanis-Jakubas K, Stempniewicz L (2012) Foraging by little auks in the distant marginal sea ice zone during the chick-rearing period. Polar Biol 35:73-81. doi:10.1007/ s00300-011-1034-x

Jenni DA (1974) Evolution of polyandry in birds. Am Zool 14:129-144

Jones IL (1994) Mass changes of Least Auklets Aethia pusilla during the breeding season: evidence for programmed loss of mass. J Anim Ecol 63:71-78

Konarzewski M, Taylor JRE (1989) The influence of weather conditions on growth of Little Auk Alle alle chicks. Ornis Scand 20:112-116

Kwasniewski S, Głuchowska M, Jakubas D, Wojczulanis-Jakubas K, Walkusz W, Karnovsky N, Błachowiak-Samołyk K, Cisek M, Stempniewicz L (2010) The impact of different hydrographic conditions and zooplankton communities on provisioning Dovekies along the West coast of Spitsbergen. Prog Oceangr 87: $72-82$

Lifjeld JT, Harding AMA, Mehlum F, Øigarden T (2005) No evidence of extra-pair paternity in the little auk Alle alle. J Avian Biol 36:484-487

Oring LW (1982) Avian mating systems. In: Farner DS, King JR, Parkes KC (eds) Avian biology. Academic Press, New York, pp 1-92
Paredes R, Insley JI (2010) Sex-biased aggression and male-only care at sea in Brünnich's Guillemots Uria lomvia and Razorbills Alca torda. Ibis 152:48-62

Paredes R, Jones IL, Boness DJ (2006) Parental roles of male and female thick-billed murres and razorbills at the Gannet Islands, Labrador. Behaviour 143:451-481

Phillips RA, Furness RW (1997) Sex-specific variation in the loss of mass by breeding Arctic Skuas. J Avian Biol 28:163-170

Quillfeldt P, Masello JF, Lubjuhn T (2006) Variation in the adult body mass of Wilson's storm-petrels Oceanites oceanicus during breeding. Polar Biol 29:372-378

Sanz JJ, Moreno J, Merino S, Tomás G (2004) A trade-off between two resource-demanding functions: post-nuptial moult and immunity during reproduction in male pied flycatchers. J Anim Ecol 73:441-447

Sealy SG (1973) Adaptive significance of post-hatching developmental patterns 386 and growth rates in the Alcidae. Ornis Scand 4:117-124

Stearns SC (1992) The evolution of life histories. Oxford University Press, New York

Stempniewicz L (1980) Factors influencing the growth of the Little Auk, Plautus alle (L), nestlings on Spitsbergen. Ekol Pol 28: $557-581$

Stempniewicz L (1995) Predator-prey interactions between Glaucous Gull Larus hyperboreus and Little Auk Alle alle in Spitsbergen. Acta Ornithol 29:155-170

Stempniewicz L (2001) Alle alle Little Auk. The journal of the birds of Western Palearctic, BWP update. Oxford University Press, Oxford, pp 175-201

Stempniewicz L, Jezierski J (1987) Incubation shifts and chick feeding rate in the Little Auk Alle alle in Svalbard. Ornis Scand $18: 152-155$

Taylor JRE (1994) Changes in body mass and body reserves of breeding Little Auks (Alle alle L.). Polish Polar Res 123: $149-168$

Trivers RL (1972) Parental investment and sexual selection. In: Campbell B (ed) Sexual selection and the descent of man. Aldine Publication, Chicago, pp 139-179

Williams TD (2005) Mechanisms underlying the costs of egg production. Bioscience 55:39-48

Williams CT, Kildaw SD, Buck CL (2007) Sex-specific differences in body condition indices and seasonal mass loss in Tufted Puffins. J Field Ornithol 78:369-378

Wojczulanis K, Jakubas D, Stempniewicz L (2005) Changes in the glaucous gull predatory pressure on Little Auks in Southwest Spitsbergen. Waterbirds 28:430-435

Wojczulanis-Jakubas K (2007) Inwestycje rodzicielskie samca I samicy u monogamicznego gatunku ptaka morskiego (alczyk Alle alle) $\mathrm{w}$ warunkach dnia polarnego. [Male and female parental investments in the monogamous seabird (little auk Alle alle) in the conditions of the midnight sun]. $\mathrm{PhD}$ thesis. University of Gdańsk, Gdańsk

Wojczulanis-Jakubas K, Jakubas D, Øigarden T, Lifjeld JT (2009a) Extra-pair copulations are frequent but unsuccessful in a highly colonial seabird, the little auk, Alle alle. Anim Behav 77: 433-438

Wojczulanis-Jakubas K, Jakubas D, Stempniewicz L (2009b) Sexspecific parental care by incubating Little auks (Alle alle). Ornis Fen 86:140-148

Zar JH (1999) Biostatistical analysis, 4th edn. Prentice Hall, Upper Saddle River, New York 